\title{
Pastoral Theology in an age of
}

\section{uncertainty}

\author{
Elaine Graham (University of Manchester, UK) ${ }^{1}$ \\ Research Associate: Department of Practical Theology \\ University of Pretoria
}

\begin{abstract}
In this article the history of pastoral and practical theology is viewed through the lens of postmodern thought. The article argues that an "age of uncertainty" has been engendered by the dissolution of many of the scientific, political and philosophical nostrums of Western modernity. Such a characterization is, however, intended to present postmodernity more as a loss of innocence than the absolute annihilation of value. It is still possible to pursue the prospects for coherent theological reflection and faithful action amidst such a fracturing of certainties. That involves searching for ways of inhabiting consistently and authentically a tradition of binding values that recognize their own contingency but also seek to create some degree of coherence and transparency. The discipline of Practical Theology should be reconceived as the articulation and excavation of sources and norms of Christian practice, the discipline that enables the community of faith to practice what it preaches. This article is a reprinted version of chapter two of the author's book Transforming practice: Pastoral Theology in an age of uncertainty, 1996, pp 38-55. Permission for republication is granted by Wipf and Stock Publishers, Eugene OR.
\end{abstract}

What is it today that demands the revisioning of Christian theology? ... It seems that it is ... that of the "passage" of history - the passing of Western bourgeois culture, with its ideals of individuality, patriarchy, private rights, technical rationality, historical progress, capitalist economy, the absoluteness of Christianity, and so on. It feels as though we are reaching the end of an historical era since we find ourselves in the midst of cognitive, historical, political,

\footnotetext{
${ }^{1}$ Prof Dr Elaine Graham is Samuel Ferguson professor of Social \& Pastoral Theology in the School of Arts, Histories and Cultures, The University of Manchester, United Kingdom. She is currently President of the International Academy of Practical Theology and a member of the International Advisory Board of HTS Theological Studies. Professor Graham is a research associate in the projects "Gender Studies" and "Theories of Practical Theology and Philosophical Hermeneutics", directed by Prof Dr Yolanda Dreyer, Department of Practical Theology, Faculty of Theology, University of Pretoria, South Africa.
} 
socioeconomic, environmental, sexual/gender, and religious changes of vast importance, comparable perhaps to the great Enlightenment that inaugurated the modern age. Can we speak, then, of a second Enlightenment, a new watershed, a new paradigm in theology?

(Hodgson 1994:53)

\section{INTRODUCTION}

What does the transition from modernity to postmodernity represent for religion, theology and Christian practice? One of the principles of modernity was its conscious secularism: the replacement of religious authority and theological speculation by humanism, reason and empiricism (Gay 1973). However, one of the implications of die postmodern return of the repressed "Other" of modernity involves a resurrection of the spiritual and the numinous. Whereas "religion" as an institutional form may be regarded as an invention of modernity - corresponding to bureaucratic logic and shaping its beliefs according to scientific reason - the emergence of postmodernity promises the radical transformation of modern religion into postmodern spiritualities (Tracy 1994). Hodgson (1994) speaks of the transition to post-modernity as a kairos or defining moment for Christian theology: a shift of "paradigms" from one period to another. Certainly, many theologians have begun to address the implications of the postmodern paradigm for the nature, tasks and status of their discipline.

A British theologian well known for his examination of the philosophical and ethical tenets of postmodernism and post-structuralism, and their ramifications for Christian faith, is Don Cupitt. He places himself in the intellectual tradition of Kierkegaard and Nietzsche: religious sceptics for whom faith cannot rest in metaphysics but in radical humanism. Cupitt argues that the transcendent God of Christian myth and dogma must diminish before individuals' spiritual journeys can really begin. A postmodern world in which all is revealed to be of human construction requires that we sever the ties of metaphysics and theological realism in order to embrace the void of nothingness (Cupitt 1994:92-116). Our religious quest becomes a self-created (and self-creating) phenomenon, yet still essentially religious: "the maintenance of God-talk with a denial of the reality of its referent" (Hart 1994:8).

Ethically, Cupitt's vision promises the end of the "sexual subjugation" and tyranny of religious totalitarianism. It proclaims liberation from all the certainties and thus abuses of power - associated with dogma, hierarchy, conformity and patriarchy. However, some kind of church is still envisaged: "as a community, a vocabulary, a starting-point, something that we are proposing eventually to transform" (Cupitt 1989:102). Cupitt models his "future church" on Latin American 
basic ecclesial communities, but as a self-consciously minimalist institution, maintaining little in the way of officials, plant or tradition. It is a sacramental and quasi-(post-?) Eucharistic community, meeting also for study, training, art and social action (Cupitt 1989:168-73).

However, it is not clear whether such groupings exist as choices or givens. Cupitt's work is heavily devoted to the problems of belief in the postmodern world; and there is a sense in which his model believer is one who grapples with her faith and then finds a congenial community and practice (of "scepticism, minimalism, emptiness, the discipline of the Void") which most suits that stance (Cupitt 1989:172). I wonder then, about the balance between "believing and belonging" (Davie 1994) in Cupitt's scheme: are we to struggle existentially with the void and hope our solutions fit those of others? I would argue that such a quest is always necessarily corporate and social, in that personal belief and commitment is preceded by our inhabitation of a multiplicity of faith-communities (some of them religious) in which the telling and retelling of narrative and meaning is already taking place.

Cupitt's point may well be that the Church's claim to pre-exist human discourse is part of its repressive strategy; but however contingent and nonrealist our social and theological worlds may be they do endure as material and ideological realities which are more than the sum of individual actions. Cupitt gestures in the direction of communities of faith and practice, but I suspect that he does ultimately privilege believing over belonging as the foundation of theological discourse. Such communities are collectives of individual choice rather than historical realities into which individuals are incorporated.

John Milbank's (1993) Theology and social theory: Beyond secular reason has attracted much debate in relation to the future of theology after postmodernity. Like many secular social theorists, Milbank emphasizes the violence done by technical rationality to the realms of spirituality, affectivity and tradition. The rise of modern social theory - especially sociology - rested upon the expulsion of religion from the dominant values of selfhood, truth, knowledge and history However, Milbank (1993:105-106) argues that secular theory has simply colonized theological terms whilst cloaking them in a spurious value-freedom that represses their true origins.

After an exhaustive critique of secular philosophy and social science, Milbank concludes that the retrieval of a renewed Christian discourse after modernity lies in the "renarration of practice" namely the rooting of Christian truth in the life and work of the Church. This is evidently a recovery of a metanarrative, because Milbank (1993:388) clearly regards the Church as 


\section{Pastoral Theology in an age of uncertainty}

the "exemplary form of human community" in which all can settle into a harmonious whole.

Unfortunately, Milbank does not elaborate on the precise workings of these communities of practice: how, in detailed terms, the actual activities of community-building, liturgy, discipleship and mission might actually express die truth of the Christian Gospel. We are left with a tantalizing vision of a Church about whose internal dynamics we can only speculate. What are these renarrated practices, who are their agents, and to what end are they directed? Critics of Milbank have surmised that the blissful homogeneity of such a reiteration of Christendom represents a denial of pluralism and heterodoxy. This is not a Church that tolerates dissent or indeed adequately reflects postmodernity's recovery of "difference". Nor is it open to critical scrutiny; the actual practices of Milbank's community are never elaborated. Apart from anything else, the diversity of Christian practice throughout history would invalidate Milbank's portrayal of harmonious continuity. Milbank's solution has a distinctly premodern, rather than postmodern, tenor; and it seems he is less interested in constructing a public theology in the midst of shifting values than espousing "a highly structured and settled ecclesial order" (Lakeland 1993:69): an enclave for the like-minded.

For others, the option for a postmodern theology is not to attempt to return to a premodern theological era, either in the form of fundamentalist, precritical religion, or in the form of a narrational community of belief and practice. Instead, a reconstructive theology is proposed, to embrace both the ambivalences of modernity and the dilemmas of postmodernity. Mark C Taylor (1992) has developed an a/theology which adapts the traditions of negative theology. He refashions apophatic spirituality - which emphasizes human contemplation of the essential mystery of God - to argue that the Divine symbolizes the void beyond human constructions of reality. Taylor invokes the Derridean notion of différance to depict a mysterious "non-absent absence" at the margins of meaning and representation. The realm of transcendence is equated with this "Other" of language, silenced by the assertion of definitive meaning, and resembles the ultimate signified which can never absolutely be encapsulated in speech. It remains as an absent presence, only ever glimpsed in the allusive interplay of texts or speech acts:

The sense of the unpresentable that haunts all presence and every presentation is sublime. The postmodern sublime, however, is not an extension of either Kant's dynamic or mathematical sublime. It results from neither the erasure nor the multiplication of form, image and representation. The sublime that is neither the fullness of the signified nor the 
plenitude of signifiers lies - always lies - between, in the differential strife of images. It is to this deserted space that we are called by an Other we can never name.

(Taylor 1992:26)

A similar mood is reflected in many of the essays in the collection Shadow of Spirit, edited by P Berry and A Wernick (1992). The illusion of fixed identities and meanings, and the death of metaphysics, has opened up new sacred spaces beyond human contingency in which it is possible to discern signs of transcendence, mystery and numinence. Many poststructuralist thinkers are redeploying traditional theological language to exemplify the transgressive sphere of what Kristeva has termed "madness, holiness and poetry". Its very existence beyond the technical-instrumental world of rationality, empiricism and foundational thinking renders it suggestive of a new form of consciousness and being which will shatter logocentric and phallogocentric reason (Berry 1992:5). However, criticism of such celebration of the playful, non-rational and spiritual expresses dissatisfaction at its indifference to ethical and political engagement. Whilst such work is philosophically exciting, it locates religion in a presocial, prediscursive Void of undifferentiated otherness and silence without adequately addressing issues of transformative practice (Williams 1992).

All these postmodern theologies share a number of features. They reject God as an absolute "Being" in place of a transcendent "Other" equated with the realm beyond human agency and rational consciousness. They also emphasize the "self-making" qualities of religion (Cupitt's metaphor is one of theologians and believers as "artists" and creators of their own reality), whether that is through narrative or other forms of Christian practice. The nature of communities of faith after postmodernity also emerges as a priority, whether that is of Milbank's neo-Augustinian Church reasserting the normative vision for humanity, or the "gathered and dispersed" groupings of Cupitt (1989:172), dedicated to the "continuous reinvention and renewal of humanity" (my emphasis).

I am intrigued by this recurrent theme in postmodern philosophical theology, that in the absence of metaphysical truth-claims independent of language, culture and context the only ultimate reality to which anyone of faith can attest is that made incarnate in, and proclaimed by, the life of intentional communities of Christian practice:

[T] presupposed. There is no purely theoretical centre of reference 
which can serve in an abstract, speculative way as a norm of identity. Truth does not yet exist; it cannot be reached by interpretation, but it has to be produced by change.

(Davis 1994:90-91)

It is perhaps surprising, therefore, to find that such themes of Christian belief and practice after postmodernity find relatively little resonance within pastoral and practical theology. ${ }^{2}$ Yet the emphasis in the work of Milbank, Cupitt and others on the domain of Christian practice, community and ecclesiology as the resolution of Christian truth-claims would seem to offer a clear opportunity for practical and pastoral theologians to contribute their own particular disciplinary resources and insights. It is possible to discern such work emerging, albeit gradually, within Christian Pastoral Theology. In the changing priorities and self-understanding of contemporary Pastoral Care there are some signs of a transition from modernity to postmodernity: a passing of particular notions of selfhood, truth and community and the identification of new points of departure.

\section{SHIFTING PARADIGMS IN PASTORAL THEOLOGY}

I shall be drawing on a number of recent publications in the field of Christian Pastoral Theology from Britain and North America in the course of this discussion. A volume of essays, Pastoral Care and social conflict from the North American Pastoral Care movement represents a particularly clear diagnosis of many of the uncertainties currently afflicting Christian Pastoral/Practical Theology (Couture \& Hunter 1995). They include a questioning of the individualism of contemporary Western Pastoral Care and a greater emphasis on social justice dimensions of Christian ministry; a move to reconnect the pastoral counseling movement (as a specific arm of Pastoral Care) with the life of local Christian congregations; a similar quest for a more distinctive theologically-based foundation for Pastoral Care as a reaction to the dominance of psychologically-derived models; and a tension between the personalist, therapeutic tradition of Pastoral Care and counseling and the symbolic, liturgical and sacramental modes of wider pastoral activity.

\footnotetext{
${ }^{2}$ There are some honourable exceptions, for example the Don Browning's $(1969,1976,1982$, $1983,1985,1987,1990,1991$ - cf Graham 1996:83-96) response to the dilemmas of ethical pluralism, although I find him remaining within a largely modernist and rationalist framework. Edward Farley (1990) also embraces postmodern themes of epistemological, political and ethical uncertainty. He uses the writings of the philosopher Emmanuel Levinas on alterity to resolve some of these issues.
} 
Another recent collection, Life-cycles: Women and Pastoral Care, attempts to articulate a feminist Pastoral Theology from the British context (Graham \& Halsey 1993). Similar shifts in the traditional contours of Pastoral Care may be evinced: a critique of the dominant patterns of giving and receiving care as simultaneously ignoring women's distinctive experiences as clients and as active agents of care within and beyond the Christian community. The retrieval of women's pastoral needs - conditioned by their passage through the life-cycle and socio-political factors - must take place by naming these experiences and challenging the taboos that surround them. Yet the challenge of gender issues to Pastoral Care does not simply involve the inclusion of women into traditions and models of ministry which otherwise remain unchanged. Instead, it is a programme for reconstituting the very values and assumptions which underpin Christian practice (Graham 1993).

A critique of Pastoral Care seeks an overview of the discipline of pastoral/practical theology in Britain and the United States (Pattison 1993). Pattison's second edition contains a critique of his earlier perceptions in die first volume. He identifies the issue of gender, and feminist critiques of conventional patterns of Pastoral Care, as the most significant development in the interval between the two editions. He also discusses some other questions: the search for an adequate definition of Pastoral Care; its defining sources and norms (the authoritative bodies of knowledge for the practice of care, particularly use of the Bible, and the role of ethics); and the relationship between the activity of Pastoral Care and the life of the gathered Church. Implicit within this is a theme shared with the other volumes: that of the problematic relationship between the practices of human or Pastoral Care and the traditions and teachings of Christian theology.

David Lyall (1995), a Scottish practical theologian, is writing for a secular audience about the religious dimensions of pastoral counseling. It is therefore not surprising that the contemporary pluralism of world-views preoccupies him. He is concerned to trace the resurgence of theological questions implicit within the counseling relationship, something he identifies as constituting a significant shift of emphasis. He draws an analogy between the changing nature of pastoral counseling in a spiritual and religious context and the life of the contemplative and activist Thomas Merton:

An early liberalism accommodating itself to the dominant secularity of die age is followed by a conservative reaction which in turn gives way to the search for a different kind of spirituality, one 
which encounters God not in religion as such, but in the suffering and striving of the world.

(Lyall 1995:106)

I cannot say whether David Lyall intends to identify this third phase of pastoral counseling as specifically postmodern, although I detect some parallels. The waning of a modern perspective on religion which assumed its ultimate decline (or reduction to privatized, individual concerns) has been superceded either by a return to premodern religious certainties or a search for more eclectic, informal spiritualities. Lyall's discussion suggests to me a movement beyond a modern and secular Pastoral Care (defined largely by the modern psychologies) towards one that seeks not the homogeneity and security of unreconstructed Christian identity, but one which embraces the contradictions and complexities of pluralism:

Set free from the compulsion to talk about God, there is new and deeper freedom to talk about God and not to talk about God. In its engagement with the secular psychotherapies, neither does pastoral counseling need to lose its Christian identity as care offered in the context of the community of faith. Set free from the compulsion to be "religious", it has a genuine freedom to point beyond the secular to the One who is the source of all healing.

(Lyall 1995:107)

Thus, Lyall's book contains a useful awareness of the necessity of working across the boundaries of secular and religious. Indeed, in an age of the resurgence of spirituality - but also in its greater diversity and reworking - many of these old boundaries may themselves be open to revision.

\section{PASTORAL THEOLOGY AND POST/MODERNITY}

Within these selected volumes, therefore, it is possible to see many shifting priorities as to the nature and identity of contemporary-Christian Pastoral Care. How do the contested areas of epistemology, ontology, agency, teleology and subjectivity, already outlined, reflect some of these changing visions?

\subsection{Privileged knowledge}

This aspect centres around debates in pastoral/practical theology about the most authoritative sources of expertise for the practice of care. Whilst the 
paradigm of pastoral counseling, with its explicit links to the values (and professional career structures) of humanistic psychologies and psychotherapy has predominated, there are signs of reorientation. This is particularly manifest in the tension expressed between sacred and secular sources of Pastoral Care and counseling (Hunter 1995:17-23). It is suggested that there has been too uncritical an acceptance of secular theories and therapies at the expense of theological models of selfhood, health and healing, sin, guilt and forgiveness in Pastoral Care (Pattison 1993:194ff).

Writing at the interface of secular and religious counseling David Lyall is well-placed to review the differences of opinion over what now constitutes definitive knowledge for the practice of care. Specifically, this is a question of how psychological and theological perspectives are to be integrated in the practice of the Christian counselor. The adoption of secular therapies in Pastoral Care is clear sign of modernity; but religious worldviews persist, even revive (Lyall 1995:134-135). Lyall emphasizes the power of stories to shape and guide identity - individual and corporate - through which effective values may be articulated. Lyall's instinct that counseling may be more open to the expression of religious value albeit within an overtly pluralist context - suggests that matters of faith are no longer regarded as privatized and personal, necessitating their "bracketing out" of the non-directive therapeutic encounter, but may actually form a crucial resource for locating our own story in relation to broader human stories (Lyall 1995:97).

\subsection{Human nature}

Within the literature surveyed here it is clear that the implicit assumptions of human personhood as encapsulated in prevailing models of Pastoral Care are subject to fundamental revision. In this respect, pastoral/practical theology is experiencing a shift of paradigms from modernity to postmodernity. Much of the twentieth-century Pastoral Care movement reflects modernist commitments to a shared and universal human nature defined by a common core of reason and self-actualizing agency; a sense that rational knowledge will provide the grounding for empirically viable therapeutic techniques; and an optimistic teleology concerning the promise of human fulfillment via the attainment and application of such rational laws of personality and salvation (Hunter 1995; Hunter \& Patton 1995). This is epitomized by the separation of pastoral counseling from the worshipping community and its absorption into a medical model of curative, clinical care. 


\section{Pastoral Theology in an age of uncertainty}

However, the notion of a universal human nature defined according to the norm of the self-actualized rational individual is undergoing revision in the face of a recovery of race, class and gender as "sites of difference". The emergence of feminist pastoral theologies suggests that traditional models of ministry and care presuppose androcentric criteria of pastoral need, norms which silence the specific experiences of women and objectify them via patriarchal constructions of appropriately feminine roles (MillerMcLemore \& Anderson 1995; Graham and Halsey 1993). Feminist perspectives call for a greater attention to the particularity and diversity of (gendered) human nature. By sustaining a notion of a universal or single definition of experience and need practitioners may actually perpetuate the interests of a patriarchal social order. Pastoral Care conducted according to unexamined axioms of personhood, may effectively reproduce oppressive norms:

The question is not whether men and women are different, but rather what value we shall place on these differences and how we shall live with them. At stake is not just the question of gender but the question of the human capacity to live with difference among persons in a planet that continues to shrink. For that reason, we regard gender studies as a necessary endeavor in pastoral theology, because the celebration of diversity and respect for human uniqueness is at stake.

(Miller-McLemore \& Anderson 1995:105)

The implications of ethnic, cultural and racial diversity are underdeveloped in contemporary pastoral literature - although emergent contributions suggest similar themes to those of feminist writing: attention to the diversity of human need, recognition of a variety of models of Pastoral Care and the importance of integrating theological understandings generated by cross-cultural differences (Ma Mpolo 1990; Harris 1991; Lartey 1993).

\subsection{Pastoral agency}

One of die most contested areas in contemporary pastoral literature concerns those persons deemed fit to dispense care; the methods by which such care is administered; and the locus of purposeful care. Since its foundation as a discrete theological discipline in the eighteenth century, Pastoral Theology - in academic and popular literature - has tended to concentrate on the qualities that characterize the good pastor. Pastoral Theology has therefore been synonymous with writings on the activity and qualities of the pastoral 
agent. For most of the modern period, until very recently, this has also meant that Pastoral Theology so understood has necessarily restricted itself to the study of the activities of male, ordained and professionally accredited persons.

Therefore, the needs of the client, or the dynamics and relationships within the Christian community as a whole, have been marginal. Alternative models of pastoral agency to that of the ordained minister - and in particular, forms of care exercised by lay women - were ignored. The supposedly normative pattern of the practice of Christian care therefore reflected the powerful and privileged status of the clergy; the contributions and gifts of women as pastoral agents were undervalued and unacknowledged. Women's unequal position in society has thus gone unchallenged by the churches because Pastoral Theology has been caught in a paradigm of "sexism and clericalism" which implicitly disavows the expertise of lay people, and especially women (Graham 1990).

In this respect the question of gender, and specifically the historical invisibility of women, exposes the limitations of old definitions of Pastoral Care and points towards new horizons. For example, Pattison (1993:194) asserts that feminism completely transforms the parameters of Pastoral Care such that its normative agent must now be considered the "non-trained woman" rather than the ordained and professionally-accredited male. ${ }^{3}$ Feminist insights thus shift both the agent and the locus of care away from the ordained minister in ecclesiastical institutions towards secular contexts or informal settings, such as parallel or alternative communities of faith, womencentred liturgies or care groups (Graham \& Halsey 1993; Ruether 1985).

An emphasis on pastoral counseling within the modern Pastoral Care movement also privileges scientific and medical models of care in preference to models of practice which deploy sacrament, prayer, sermon or symbol (Hunter 1995). However, as the feminist reconstruction of Pastoral Theology indicates, the tradition is being revised to provide new sources and norms for personhood, healing and community. This restores a broader definition of pastoral activity as encompassing not only individual care and counseling, but a diverse set of pastoral practices:

The care of the church is constituted by the whole variety of ways the life of the church seeks to promote the flourishing of God's creation in enactment of the gospel: through worship,

\footnotetext{
${ }^{3}$ However, this should not be used as an argument against offering training to such women as a means of enhancing their expertise, simply a reminder that such education and accreditation should be appropriate to the needs of women ministers, lay and ordained (see Parsons 1993)!
} 
prayer, Bible study, fellowship, social ministry, music, preaching, and so forth.

(Lyon 1995:97)

Clearly, there are complex ethical and political dimensions to the caring relationship, and it cannot be assumed that the counseling or helping encounter is immune from the values and power structures of society at large. The potential for die abuse of power in the therapeutic relationship has become a matter for concern in recent years, and is emerging into Pastoral Theology as well (Graham 1993; Poling 1991, 1995).

Contemporary writers thus seek a greater equality in the pastoral encounter, arguing that the dynamics of power and difference (of gender, race, class, sexuality and professionalism) need to be addressed honestly and openly. The emphasis is on the mutuality of care in contrast to the formality and hierarchy of old. It is held to be a more authentic expression of Divine kenosis and vulnerability and stresses a model of Pastoral Care as shared companionship on life's journey rather than the imbalance of client/expert or sheep/shepherd (Campbell 1981; Pattison 1993).

\subsection{Teleology - or the aims and ends of care}

However, such a model of companionable care raises for many commentators the problematic issue of moral judgment and discipline in Christian Pastoral Care. Whilst the unquestioned hierarchy of status and expertise of older models of pastoral relationship seem inappropriate for the post/modern era, there are also questions to be asked about the degree of moral authority a pastor (however chosen and accredited) may be called upon to exercise. The twentieth-century tradition of non-directive or eductive counseling advocates a non-judgmental stance on the part of the pastor. In part, this may reflect the extent to which the contemporary Pastoral Care movement is embedded in a modern grand narrative of progress and amelioration. It is implicitly committed to a humanist tradition of faith in the powers of reason, optimism and scientific method and practice to effect human healing and growth:

In the therapeutic perspective the distortions of human life are believed to be largely of contingent historical and social origin, accessible to human effort and intelligence; thus human beings are capable of participating in significant ways with God in saving and restoring human life at its deepest ("spiritual") levels of struggle and distortion. Such commitments are cautiously 
optimistic concerning human powers and possibilities, compared with the exclusive emphasis on sin, the bondage of the will, and dependency on divine grace that has characterized much of the Western religious tradition.

(Hunter 1995:18-19)

Thus, the ultimate goal of the modern Pastoral Care movement has been one of personal wholeness and well-being; but the individual is seen as possessing an innate orientation towards such self-actualization. Certainly, there is some concession to moral judgment in the form of confrontation in the counseling relationship; but this seems orientated more towards encouragement of ethical autonomy than obedience to external moral codes. Such a bracketing of pastoral discipline (traditionally an emphasis of pastoral ministry) may have been a welcome antidote to the more severe forms of judgmentalism, and allowed alternative models to flourish which emphasized unconditional forgiveness and the importance of self-esteem (as in, e g, Paul Tillich's stress on "acceptance"). Arguably, however, contemporary Pastoral Care finds itself with an impoverished vocabulary of moral discernment - in relation to the individual and the collective - as a result.

Another sign of change is a growing concern for the social and political dimensions of care. The personalist tradition of Pastoral Care, with its focus on the immediate feelings and responses of the client, may obscure the extent to which social and economic factors enhance or impede our growth to full personhood. It also neglects the sense in which we are always already relational selves, formed by communal and social contexts (Graham 1995; Marshall 1995). James Poling (1995) argues that the modern Pastoral Care movement was concerned to listen to the voices of suffering and dispossession from its earliest inception. He argues that die contemporary postmodern challenges of racial and gender justice (and, we might add, the economic dispossession of the poor, locally, nationally and globally) demand a similar response of compassion which goes beyond individual amelioration. It will require the reform and revision of the dominant models of Pastoral Care:

The pastoral care movement has two choices. Either it is still a reform movement to change church and society, or it is a profession within the established patriarchal church and society concerned mainly with its own financial future, accreditation, and making sure it has a secure place for its members. If our Pastoral Care movement decides to return to its earlier reformist 
goals, it must respond to die present crisis in the area of sexuality by focusing on issues of the liberation of women, African Americans, and gays and lesbians from the traditional sexual ethics that support male dominance.

(Poling 1995:122)

The feminist maxim that "the personal is political" is nowhere more true than when applied to Christian Pastoral Care. As the examples of womencentred care are making clear, women's personal circumstances and pastoral needs are not simply individual problems but occur within a social context of health and illness, reflect the influence of cultural norms and the dynamics of family life on dominant expectations of the giving and receiving of care, and reveal the impact of structural and institutional trends in public policy and socio-economic change (Graham \& Halsey 1993; Marshall 1995). Changing understandings of the pastoral responses most appropriate to the needs of women therefore serve as a prime example of pastoral/practical theology's revision of its priorities away from models of amelioration or crisis management towards the promotion of more proactive strategies of social change and political intervention (Graham 1990).

\subsection{The subject of care}

Postmodern perspectives portray the self as a subject-in-relation, whose identity is forged within the complex interplay of economic, cultural and political factors. Contemporary pastoral/practical theology is gradually revising its own implicit ideals of the person to encompass such contexts. The subject of care is shifting from that of a self-actualized individual for whom care functions primarily at times of crisis towards one of a person in need of nurture and support as she or he negotiates a complexity of moral and theological challenges in a rapidly-changing economic and social context (Pattison 1993).

The task of care is thus to equip individuals and communities with the resources by which they might respond to such complexity - be it in the form of changing conditions of work, citizenship, relationships or gender roles. In this respect, Lyall's emphasis on counseling as facilitating the stories by which we learn to locate ourselves and make sense of our world emerges as one strategy for nourishing a sense of personal identity within a wider complex of cultural, religious and political factors. However, such a model may be as much about disturbing as establishing a sense of security and locatedness, given the complexity of human experience and identity: 
The important notion is not to do away with the conflict but to utilize it to create opportunities for communities to engage in theological reflection about what it means to be an inclusive and meaningful faith community in a complex world. Congregations fractured by the issues of class, race, sexual orientation, or gender need opportunities to enter into moral discourse and not merely to dismiss those with whom they disagree.

(Marshall 1995:175-6)

\section{CONCLUSION}

The preceding issues reflect signs of restlessness and dissatisfaction with conventional wisdom within pastoral/practical theology, and a search for new, more inclusive paradigms. The practice of Pastoral Care has been central to die disciplinary identity of Pastoral/Practical Theology; but a central concern in much of die contemporary literature is a search for an adequate definition. The dominance of therapeutically-derived models of care is being displaced by a rediscovery of wider horizons: pastoral activity as entailing liturgy, preaching, Christian nurture, social action, community formation, spiritual direction as well as crisis counseling. A greater diversity of pastoral practice also broadens prevailing notions of die methods of pastoral ministry. The use of secular therapies founded on methods and objectives of humanist selfactualization is supplemented by more symbolic and sacramental models. Whilst the pastoral conversation in the form of one-to-one interview may appropriately be considered a legitimate form of pastoral encounter (confession, spiritual direction or pastoral counseling), other forms of corporate practice - most especially in liturgical and ritual forms - may also be seen as the occasion of healing, reconciliation, support and induction.

The emphasis on a diversity of practices also challenges the primacy of such activities as the exclusive domain of the ordained (male) pastor. The gathered community may also be the agent of Christian practice, either in its enactment of ritual functions, or by its emphasis on the shared ministry of the laity. However, there may still be proper scope for specialist ministries, and this raises questions of how pastors, lay and ordained, might be selected and trained, and what might constitute definitive bodies of knowledge by which their actions and values are guided.

I have also identified considerable equivocation concerning the proper locus of Christian pastoral activity. There is concern that Pastoral Care became privatized under modernity, both in the over-individualistic emphasis of humanistic psychotherapies and in the bracketing of religious 


\section{Pastoral Theology in an age of uncertainty}

and theological values out of secular care. Accordingly, there are calls to relocate the focus of care back into the communal context of the regular gathered Christian congregation. However, this also raises the question of the responsibility of the Christian Church for the wider world; is pastoral ministry merely about building up the faithful, or is there, as many contemporary writers suggest, also a wider agenda of social justice? It may also be important to note that "lay ministry" can be interpreted either as inducting church members into ecclesial roles and offices, or as facilitating Christians to exercise faithful vocation in their "secular" life and work.

Finally, the aims and objectives of Pastoral Care have been fundamentally questioned. Is the aim of care the amelioration of existential and personal distress and trouble, or the pursuit of proactive projects to establish social justice? Such a dichotomy may in fact be establishing a false distinction between broadly "pastoral" or "prophetic" ministries; but a number of writers are seeking to challenge the dominance of a broadly curative model of "crisis-management" in favor of perspectives which seek to ground the functions of ministry in wider understandings of Christian formation (Pattison 1993:199). For such models, the aim of care is to build up the believer to exercise an effective ministry in the world, or to define and nurture an image of "Christian perfection" by which moral and social responsibility can be guided. However, if the Church is to perceive its pastoral role in terms of programmes of social intervention, in whatever form, the question remains as to the normative values by which such campaigns for justice and change are guided. Will such pastoral/prophetic action reflect humanistic models of universal reason and progress; or more distinctive visions of Christian hope and obligation?

My survey of the shifting paradigms of pastoral/practical theology has highlighted a move towards a diversification of practices to include sacramental as well as therapeutic and clinical models, a reclamation of the moral and normative nature of care and a shift towards Christian formation within the community of faith as well as amelioration of individual distress. A proposition, current amongst many pastoral/ practical theologians, is that the changing priorities of postmodern Pastoral Care actually represent not a break with past tradition, but a recovery and reaffirmation of Christian roots. But such perennial pastoral functions may still require reinterpretation for a postmodern age. Current tensions in the literature reveal shifting paradigms in which old certainties surrounding appropriate knowledge, authoritative agency, normative personhood and ultimate ends are undergoing 
transformation and may require not a return to premodern axioms but a forging of new programmes out of the old. However, there is still a major problem concerning the role of the historic narratives of the Christian faith in informing purposeful action, and the relationship of the inherited tradition to the changing context that confronts every new generation.

In a lecture to the Clinical Theology Association on the future of Christian pastoral counseling, Gordon Oliver contrasted the metaphors of "boundary" and "horizon" and suggested that the latter is a more appropriate, inclusive and liberating perspective by which Christians may orientate their visions of mission and ministry (Oliver 1991). For Oliver, "boundaries" circumscribe the possible and the acceptable, suggesting security, the known and the achievable. "Horizons", by contrast, indicate, and invite "mystery, discovery, exploration, and the possibility of further encounters" (Oliver 1991:9). The authentic practice of the Church necessarily occupies the tension between the two: "the limitations of the present and the possibilities of transcendence which are suggestive of a vision of ministry and Pastoral Care that relates to boundaries as if they were horizons" (Oliver 1991:9).

I find the twin images of boundaries and horizons very evocative in relation to a new vision for Pastoral Theology. The cultural, economic and intellectual shifts of contemporary society present Christian theology with new horizons of pluralism and diversity. However, there is still a concern to uphold questions of value and to retain a clear identity for Christian ministry in the midst of such a changing and complex culture. The distinctiveness of a theological identity informing pastoral practice, the nature of the communities within which Pastoral Care is exercised and the principles on which human flourishing and social justice are to be founded, all suggest a concern for the boundaries by which purposeful and authentic Christian activity might be evaluated. However, my overview of contemporary Pastoral Theology in this article suggests that many of the old boundaries no longer seem adequate; in fact, they are perceived as exclusive, constraining and inappropriate. It remains to be seen whether a reiteration of historical tradition in Pastoral Theology will provide contemporary Christians with adequate sources and norms for the challenges of the postmodern world. In the context of radical shifts in Western culture in which consensus surrounding a likely vision of hope and obligation is fragmenting into many competing horizons, and the norms and values of Christian care are themselves under duress, the reconstructive task is complex. 


\section{Works Consulted}

Abbott, W M (ed) 1966. The documents of the Vatican II. London: Chapman.

Adams, J E 1976. The use of Scriptures in counseling. Grand Rapids, MI: Baker.

Balmforth, H, Dewar, L, Hudson, C E \& Sara, E W 1937. An introduction to Pastoral Theology. London: Hodder \& Stoughton.

Bebbington, D W 1989. Evangelicalism in modern Britain. London: Unwin Hyman.

Belton, F G 1916. A manual for confessors. London: Mowbray.

Berry, $P$ 1992. Introduction, in Berry \& Wernick 1992:1-8.

Berry, P \& Wernick A (eds) 1992. Shadows of Spirit: Postmodernism and religion. London: Routledge.

Brennan, J H 1967. Pastoral Theology, in McDonald, W J (ed), New Catholic Encyclopedia, 1080-1084. New York: McGraw-Hill.

Browning, D S 1969. The influence of psychology on theology, in Oglesby, W B (ed), The new shape of Pastoral Theology: Essays in honor of Seward Hiltner, 121135. Nashville, TN: Abingdon.

Browning, D S 1976. The moral context of Pastoral Care. Philadelphia, PA: Westminster.

Browning, D S 1983. Religious ethics and Pastoral Care. Philadelphia, PA: Fortress.

Browning, D S 1985. Practical Theology and political theology. Theology Today XLII(1), 15-33.

Browning, D S 1987. Practical Theology and religious education, in Mudge, L S \& Poling, J N (eds), Formation and reflection: The promise of Practical Theology, 79-102. Philadelphia, PA: Fortress.

Browning, D S 1990. Ethics and Pastoral Care, in Hunter, R J (ed), Dictionary of Pastoral Care and Counseling, 364-366. Nashville, TN: Abingdon.

Browning, D S 1991. A fundamental Practical Theology: Descriptive and strategic proposals. Minneapolis, MN: Fortress.

Burkhart, J E 1983. Schleiermacher's vision for theology, in Browning, D S (ed), Practical Theology: The emerging field in theology, church and world, 42-60. San Francisco, CA: Harper \& Row.

Campbell, A V 1981. Rediscovering Pastoral Care. London: Darton, Longman \& Todd.

Clebsch, W A \& Jaekle, C R 1964. Pastoral Care in historical perspective. Englewood Cliffs, NJ: Prentice Hall.

Couture, P D \& Hunter, R J (eds) 1995. Pastoral Care and social conflict. Nashville, TN: Abingdon.

Cupitt, D 1989. Radicals and the future of the church. London: SCM Press.

Cupitt, D 1994. After all: Religion without alienation. London: SCM Press.

Davie, G 1994. Religion in Britain since 1945: Believing without belonging. Oxford: Blackwell.

Davies, M 1991. Industrial mission: The anatomy of a crisis. Manchester: William Temple Foundation.

Davis, C 1994. Religion and the making of society. Cambridge: Cambrigde University Press.

Day Williams, D 1961. The minister and the cure of souls. New York: Harper.

Dewar, L \& Hudson, C E 1932. A manual of pastoral psychology. London: Phillip Allen. 
Dicks, R L 1944. Pastoral work and personal counseling. New York: Macmillan. Dyson, A O 1983. Pastoral Theology: Toward a new discipline. Contact: The Interdisciplinary Journal of Pastoral Studies 78, 2-8.

Evans, E 1961. Pastoral Care in a changing world. London: Epworth.

Evans, J 1995. Feminist theory today: An introduction to second-wave feminism. London: Sage.

Farley, E 1983. Theology and practice outside the clerical paradigm, in Browning, D $\mathrm{S}$ (ed), Practical Theology: The emerging field in theology, church and world, 21-41. San Francisco, CA: Harper \& Row.

Farley, E 1983. Theologia: The fragmentation and unity of theological education. Philadelphia, PA: Fortress.

Farley, E 1987. Interpreting situations: An inquiry into the nature of Practical Theology, in Mudge, L S \& Poling, J N (eds), Formation and reflection: The promise of Practical Theology, 1-26. Philadelphia, PA: Fortress.

Farley, E 1990. Good and evil: Interpreting a human condition. Minneapolis, MN: Fortress.

Fuller, R C 1986. Americans and the unconscious, Oxford: Oxford University Press.

Gay, P 1973. The enlightenment: An interpretation, Vol I: The rise of modern paganism. London: Wildwood House.

Gibbs, M \& Morton, R 1964. God's frozen people. London: Collins.

Gladden, W 1989. The Christian pastor and the working church. Edinburgh: T\&T Clark.

Graham, E L 1990. Pastoral Theology, feminism and future. Contact: The Interdisciplinary Journal of Pastoral Studies. 103, 2-9.

Graham, E L 1993. The sexual politics of Pastoral Care, in Graham, E L \& Halsey, M (eds), Life-cycles: Woman and Pastoral Care, 210-224. London: SPCK.

Graham, E L 1996, Pastoral Theology in an age of uncertainty. London: Mowbray. (A Cassell Imprint.)

Graham, E L \& Halsey, M (eds) 1993. Life-cycles: Woman and Pastoral Care. London: SPCK.

Graham, L K 1995. From relational humannes to relational justice: Reconceiving Pastoral Care and counseling, in Couture, P D \& Hunter, R J (eds), Pastoral Care and Social Conflict, 220-234. Nashville,TN: Abingdon.

Harris, J H 1991. Pastoral Theology: A black-church perspective. Minneapolis, MN: Fortress.

Hart, D A 1994. On not quite taking leave of Don. Modern believing (New Series) 35(4), 6-9.

Hiltner, S 1958. Preface to Pastoral Theology. Nashville, TN: Abingdon.

Hodgson, P C 1994. Winds of the Spirit: A constructive Christian theology. London: SCM.

Holifield, E B 1983. A history of Pastoral Care in America: From salvation to selfrealisation. Nashville, TN: Abingdon.

Howe, L T 1984. Pastoral Care in today's church and world. Modern Churchman (New Series) 26(4), 31-41.

Hunter, R J 1995. The theurapeutic tradition of Pastoral Care and counseling, in Couture, P D \& Hunter, R J (eds), Pastoral Care and social conflict, 17-31. Nashville, TN: Abingdon. 
Imbelli, R P \& Groome, T H 1992. Signpost towards a Pastoral Theology. Theological Studies 53(1), 127-137.

Lakeland, P 1993. Encountering the postmodern. The Month, February, pp 63-70.

Lartey, E Y 1993. African perspectives on Pastoral Theology. Contact: The Interdisciplinary Journal of Pastoral Studies 112, 3-11.

Lyall, D 1995. Counselling in the pastoral and spiritual context. Buckingham: Open University Press.

Lyon, K B 1995. Aging and the conflict of generations, in Couture, P D \& Hunter, R J (eds), Pastoral Care and social conflict, 86-98. Nashville, TN: Abingdon.

Ma Mpolo, M 1990. African Pastoral Care movement, in Hunter, R J (ed), Dictionary of Pastoral Care and Counseling, 11-12. Nashville, TN: Abingdon.

McCarthy, M 1990. Vatican II and Pastoral Care, in Hunter, R J (ed), Dictionary of Pastoral Care and Counseling, 1298-1300. Nashville, TN: Abingdon.

McGovern, A F 1989. Liberation theology and its critics. Maryknoll, NY: Orbis.

McNeil, J T 1951. The history of the cure of souls. New York: Harper \& Row.

Mahoney, J 1987. The making of moral theology. Oxford: Oxford University Press.

Marshall, J L 1995. Pastoral Care with congregations in social stress, in Couture, P D \& Hunter, R J (eds), Pastoral Care and social conflict, 167-179. Nashville, TN: Abingdon.

Milbank, A J 1993. Theology and social theory: Beyond secular reason. $2^{\text {nd }}$ ed. Oxford: Blackwell.

Miller-McLemore, B J \& Anderson, H 1995. Gender and Pastoral Care, in Couture, P D \& Hunter, R J (eds), Pastoral Care and social conflict, 99-113. Nashville, TN: Abingdon.

Mitchell, K R 1990. Review of Pastoral Counsel. Journal of Pastoral Care XLIV(3), 290-292.

Nouwen, H J M 1969. Anton T Boisen and theology through living human documents. Pastoral Psychology, 49-63.

Oates, W 1953. The Bible in Pastoral Care. Philadelphia, PA: Westminster.

Oates, W 1962. Protestant Pastoral Counseling. Philadelphia, PA: Westminster.

Oates, W 1974. Pastoral Counseling. Philadelphia, PA: Westminster.

Oden, T C 1966. Kerygma and counseling. Philadelphia, PA: Westminster.

Oden, T C 1984. The care of souls in the classical tradition. Philadephia, PA: Fortress.

Oden, T C 1987. Becoming a minister. New York: Crossroad.

Oden, T C 1989a. Ministry through word and sacrament. New York: Crossroad.

Oden, T C 1989b. Pastoral counsel. New York: Crossroad.

Oglesby, W B Jr (ed). 1969. The new shape of Pastoral Theology: Essays in honor of Seward Hiltner. Nashville, TN: Abingdon.

Oliver, G 1991. Counselling, anarchy and the kingdom of God. Lingdale Papers 16.?? Oxford: Clinical Theology Association.

Pattison, S 1993. A critique of Pastoral Care. $2^{\text {nd }}$ ed. London: SCM.

Pattison, S 1994a. A vision of Pastoral Theology. Edinburgh. (Contact Pastoral Monograph 4.)

Peters, J 1986. Frank Lake: The man and his work. London: Darton, Longman \& Todd.

Poling, J N 1991. The abuse of power: A theological problem. Nashville, TN: Abingdon. 
Poling, J N 1995. Sexuality: A crisis for the churches, in Couture, P D \& Hunter, R J (eds), Pastoral Care and social conflict, 114-124. Nashville, TN: Abingdon.

Rogers, C R 1942. Counseling and psychotherapy. Boston, MA: Houghton Miffin.

Rouse, R \& Neill, S C (eds) 1967. A history of the ecumenical movement, 1517-1948, $2^{\text {nd }}$ ed. London: SPCK.

Ruether, R R 1992. Sexism and God-talk: Toward a feminist theology, $2^{\text {nd }}$ ed. London: SCM.

Schleiermacher, E F 1966. Brief outline study of theology. tr by T N Tice. Richmond, VI: John Knox.

Stokes, A 1985. Ministry after Freud. New York: Pilgrim.

Sunderland, R H 1990. Lay Pastoral Care and Counselling, in Hunter, R J (ed), Dictionary of Pastoral Care and Counseling, 632-634. Nashville,TN: Abingdon.

Taylor, M C 1992. Reframing postmodernisms, in Berry, P \& Wernick, A (eds), Shadow of Spirit: Postmodernism and religion, 11-29. London: Routledge.

Thornton, M 1958. Pastoral Theology: A reorientation. London: SPCK.

Thurneysen, E 1962. A theology of Pastoral Care. London: John Knox.

Tillich, P 1948. The shaking of foundations. New York: Scribner.

Tillich, P 1951/57/63. Systematic theology, 3 Vols. London: Nisbet.

Tillich, P 1952. The courage to be. New Haven, CT: Yale University Press.

Tillich, $P$ 1959. The theological significance of existentialism and psychoanalysis, in Kimball, R C (ed), Theory of culture. New York: Oxford University Press.

Tracy, D 1994. Theology and the many faces of postmodernity. Theology Today 51(1), 104-114.

Van Oosterzee, J J 1878. Practical Theology: A manual for theological students, tr by M J Evans. New York: Scribner.

Vinet, A 1855. Pastoral Theology: The theory of a gospel ministry. Edinburgh: T\&T Clark.

Waterhouse, E S 1939. Psychology and pastoral work. London: Hodder \& Stoughton. Weatherhead, L D 1929. Psychology in the service of the soul. London: Epworth. Weber, H R \& Neill, S C 1963. The layman in Christian history. London: SCM. Wickham, E R 1957. Church and people in an industrial city. London: Lutterworth. Williams, R 1992. Hegel and the gods of postmodernity, in Berry, P \& Wernick, A (eds), Shadow of Spirit: Postmodernism and religion, 72-80. London: Routledge. 